Placing Antifreeze Concrete at Grand Forks Air Force Base

Charles Korhonen and Peter Semen

April 2005

US Army Corps of Engineers ${ }_{\circledast}$

Engineer Research and Development Center 


\section{Placing Antifreeze Concrete at Grand Forks Air Force Base}

Charles Korhonen and Peter Semen

Cold Regions Research and Engineering Laboratory U.S. Army Engineer Research and Development Center 72 Lyme Road

Hanover, New Hampshire 03755

Approved for public release; distribution is unlimited

Prepared for Office of the Chief of Engineers, Grand Forks Air Force Base, Master Builders Technologies, and Office of the Assistant Secretary of the Army for Installations and Environment 


\section{ABSTRACT}

The first airfield pavement application of a recently developed antifreeze technology for cold weather concreting was demonstrated in February 2004 on an unreinforced section of a parking apron at the Grand Forks Air Force Base (GFAFB) in North Dakota. The technology, which combines ordinary concrete admixtures into a formulation that depresses the freezing point of water and accelerates the hydration rate of portland cement, was the product of a three-year study conducted for the Federal Highway Administration and completed in February 2004. One of the eight admixture combinations developed in that study was used to convert a standard concrete mixture into antifreeze concrete at GFAFB. Two trial batches of concrete made on the day prior to working on the apron afforded the ready-mix producer ample time to adjust admixture dosages to produce a workable concrete. Four truckloads of concrete were sequentially batched at the ready-mix plant and dosed with the antifreeze formulation at the jobsite. Except for the second truckload, which was later discovered to have damaged mixing fins inside its drum, the antifreeze concrete batched in this study behaved like normal fast-setting concrete during mixing, at the time of placement, and throughout finishing. The apron section was ready for traffic two days after placement in subfreezing weather.

DISCLAIMER: The contents of this report are not to be used for advertising, publication, or promotional purposes. Citation of trade names does not constitute an official endorsement or approval of the use of such commercial products. All product names and trademarks cited are the property of their respective owners. The findings of this report are not to be construed as an official Department of the Army position unless so designated by other authorized documents. 


\section{CONTENTS}

1
2
3
INTRODUCTION

\section{ILLUSTRATIONS}

Figure 1. Relationship between the concentration of solids contributed by the admixtures to the water in the concrete and the freezing point of freshly mixed concrete made with admixture combination MB IV ................6 6

Figure 2. Repair section instrumented with thermocouples ................................. 7

Figure 3. Freezing points determined by placing 50.8- by $101.6-\mathrm{mm}$ cylinders of concrete into a picnic cooler containing dry ice ........................ 11

Figure 4. Placing and raking intermediate layers of concrete ............................ 12

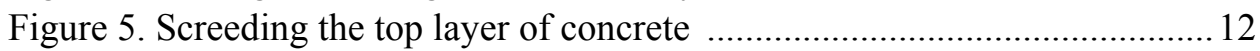

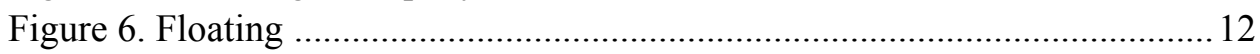

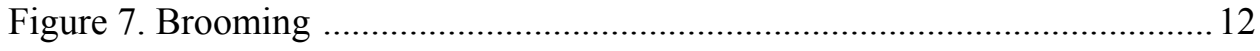

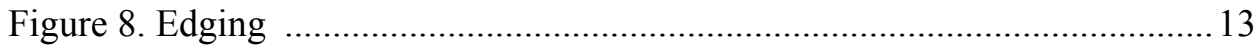

Figure 9. Laying insulation blankets in the wind and holding them

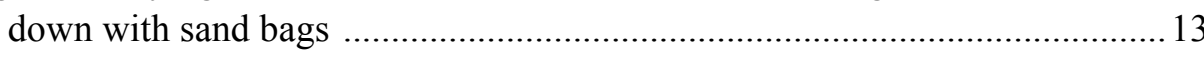


Figure 10. Maturity curve based on compressive strengths and timetemperature history from the cylinders cast during placement of the slab .... 14

Figure 11. Predicted strength using the maturity curve from the cylinders and the time-temperature history from the top, bottom, and corner thermocouple locations

Figure 12. Temperatures from three locations in the slab and the ambient air from February 23 through March 3 .16

Figure 13. Crack that developed in the concrete approximately 3 hours after the insulation blanket was removed

\section{TABLES}

Table 1. Comparison of suggested mixture proportions for standard concrete and admixture combination MB IV to two trial batches of antifreeze concrete 4

Table 2. Mixture proportions for the four truck loads of antifreeze concrete used in this project .8

Table 3. Properties of the fresh concrete . .9

Table 4. Compressive strength and maturity index data from cylinders cured 24 hours in the field and the rest of the time in standard laboratory conditions 14 


\section{PREFACE}

This report was prepared by Charles Korhonen and Peter Semen, Research Civil Engineers of the Civil Engineering and Infrastructure Branch, U.S. Army Engineer Research and Development Center (ERDC), Cold Regions Research and Engineering Laboratory (CRREL), Hanover, New Hampshire. The fieldwork was funded by direct and in-kind contributions from CRREL, Grand Forks Air Force Base, and Master Builders Technologies, while the writing and publication of this report was funded by the Commercialization of Technologies to Lower Defense Costs (CT/LDC) Program as part of a contract with the Office of the Assistant Secretary of the Army for Installations and Environment, Safety and Occupational Health, to facilitate the commercialization of technologies that meet critical military needs.

The authors acknowledge the excellent support from Lt. Wayne Kinsel and Janelle Zweifel of the $319^{\text {th }}$ Civil Engineering Squadron, Grand Forks Air Force Base, in coordinating the concrete workers from the Base Horizontal Shop; David Tokar, Midwest Testing Laboratory, for quality assurance testing; and Ed Fellner, Strata Corp., for batching the concrete. Acknowledgments also go to Steve Zinniel, Master Builders, for using his pumps to dose the admixtures into the trucks. Master Builders, Cleveland, Ohio, donated the admixtures. Capt. Erik Sell, Air Force Institute of Technology, set up this field demonstration. Dr. Ray Rollings and Lynette Barna of CRREL technically reviewed this report.

This report was prepared under the general supervision of Steven Flanders, Chief, Civil and Infrastructure Engineering Branch; Dr. Lance Hansen, Deputy Director; and James L. Wuebben, Acting Director, CRREL.

The Commander and Executive Director of ERDC is COL James R. Rowan, EN. The Director is Dr. James R. Houston. 


\title{
Placing Antifreeze Concrete at Grand Forks Air Force Base
}

\author{
CHARLES KORHONEN AND PETER SEMEN
}

\section{INTRODUCTION}

In February 2004, at Grand Forks Air Force Base (GFAFB) in North Dakota, we worked with the U.S. Air Force 319th Civil Engineering Squadron to replace a 610-mm-thick pavement slab in subfreezing weather using a newly developed antifreeze admixture technology to protect the concrete. Ordinarily this feat could not be done using normal concrete without some form of thermal protection. However, in a study for the Federal Highway Administration (FHWA), CRREL demonstrated that it is possible to develop an antifreeze concrete using commercial off-the-shelf admixtures that can fully cure at internal temperatures of $-5^{\circ} \mathrm{C}$ (Korhonen et al. 2004). The work at GFAFB was the first application of this new technology outside the FHWA study.

This report briefly describes the background leading up to this project and details the trial batching, the work needed to replace the pavement slab, and the performance of the concrete in cold weather. Data are presented from freezing point, slump, and air content measurements obtained in the field. Compressive strengths from field-cast cylinders tested in a commercial laboratory coupled with temperatures taken from the cylinders and the pavement are used to estimate the in-place strength of the concrete. 


\section{BACKGROUND}

Past studies have demonstrated the feasibility of using chemicals to depress the freezing point of water and accelerate the hydration rate of cement to allow concrete construction to progress in cold weather (Korhonen 2002). However, little has been done to commercialize this approach to winter concreting, primarily because no acceptance standards have been developed for antifreeze admixtures, and there are few who want to assume liability for using new technology without industry standards. Rather than wait for standards to be developed and special admixtures to be marketed, CRREL initiated a study in 2000 with the FHWA to develop an antifreeze technology using existing industry-approved admixtures that would be suitable for today's highway paving and repair needs in subfreezing weather. The study consisted of evaluating commercially available admixtures under controlled laboratory conditions and in field settings to find the correct combination of admixtures that could accelerate curing, ensure workability, provide adequate freezing point depression, and not harm the freeze-thaw durability of concrete. By late 2003, CRREL had uncovered several admixture combinations that allowed concrete to fully cure while its internal temperature was below freezing and that resulted in concrete that was as strong and durable as normal concrete cured during the summer. In addition, the cost was less than normal concrete made using conventional winter construction techniques. In February 2004, Korhonen et al. (2004) reported to the FHWA that the tools to design, mix, place, and cure concrete in cold weather were prepared and ready for immediate use.

The U.S. Air Force needs to build, maintain, and upgrade airfield pavements in all climates around the world, so Air Force Institute of Technology invited CRREL to demonstrate a full-depth repair to a section of pavement at the Grand Forks Air Force Base in North Dakota under winter conditions. 


\section{WORKING WITH THE CONCRETE}

\section{Preconstruction Trial Batches}

The FHWA report (Korhonen et al. 2004) recommends making trial batches of antifreeze concrete fashioned from standard concrete mixtures before construction startup to allow the ready-mix producer time to adjust the individual admixture dosages and overall dosing sequence to produce an antifreeze concrete that behaves like normal concrete at the time of placement.

Of the eight admixture combinations offered in the FHWA report, admixture combination MB IV was arbitrarily chosen for this project. Table 1 shows the suggested make-up of MB IV and the mixture proportions of the standard concrete selected and of two trial batches of antifreeze concrete. Because the jobsite was at least a half hour away and antifreeze concretes tend to rapidly lose slump and air content 30-40 minutes after batching (Korhonen et al. 2004), it was decided that some of the admixtures would be mixed into the concrete at the jobsite to delay these losses. Thus, some mixing water would have to be withheld from the concrete at the batch plant to account for the water in the jobsite admixtures. The trial batches were made on Monday, February 23.

For the first trial batch, more mixing water than necessary was withheld from the concrete. Water was withheld to account for the water in the admixtures, but extra water was also withheld as a precaution against the aggregate being wetter than expected. Moisture control is critical to obtain a desired freezing point - too much water and the concrete becomes unable to resist freezing. It is relatively easy to measure the moisture content of aggregate grab samples but virtually impossible to assure how much water actually gets into the mix from the batched aggregates. Thus, it was better to batch a potentially dry mix to which water could later be added, if needed, than a mix that was too wet and had to be discarded.

Table 1 shows the proportions for the first trial batch of concrete. The cement, aggregate, air entrainer, plasticizer, and water were loaded by the readymix plant into the drum of a concrete-mixing truck. The relatively dry concrete (w/c 0.275) was mixed for 2 minutes while the truck was driven a short distance to another location at the plant. To simulate transit to the jobsite, the concrete was then slowly agitated (2-4 rpm) for 30 minutes with the truck parked. The corrosion inhibitor ${ }^{*}$ was then pumped into the drum and mixed for 3 minutes.

* Potentially, any admixture that met the requirements of ASTM C 494 or was a commercial product otherwise accepted by industry practice could be acceptable for antifreeze concrete. The objective is to select the correct combination of admixtures that would perform well in cold weather. 
Table 1. Comparison of suggested mixture proportions for standard concrete and admixture combination MB IV to two trial batches of antifreeze concrete. Also shown are test results from the two trial batches of fresh antifreeze concrete. The expected 28-day compressive strength from the standard concrete is $38 \mathrm{MPa}$.

\begin{tabular}{|c|c|c|c|c|c|}
\hline \multirow{2}{*}{\multicolumn{2}{|c|}{ Ingredients }} & \multirow[b]{2}{*}{$\begin{array}{l}\text { Standard } \\
\text { concrete }\end{array}$} & \multirow{2}{*}{$\begin{array}{c}\text { Suggested } \\
\text { dosages for } \\
\text { MB IV }\end{array}$} & \multicolumn{2}{|c|}{ Trial batches $\left(2.3 \mathrm{~m}^{3}\right)$} \\
\hline & & & & 1 & 2 \\
\hline \multicolumn{2}{|c|}{$\begin{array}{l}\text { Cement }\left(\mathrm{kg} / \mathrm{m}^{3}\right) \text {, Type I/lI } \\
\text { Aggregate }\left(\mathrm{kg} / \mathrm{m}^{3}\right)\end{array}$} & 363 & - & 364 & 365 \\
\hline \multicolumn{2}{|c|}{$\begin{array}{l}\text { Aggregate }(\mathrm{kg} / \mathrm{m}) \\
\text { Coarse }-19 \mathrm{~mm} \text { NMSA } \\
\text { Fine - sand }\end{array}$} & $\begin{array}{r}1053 \\
736\end{array}$ & - & $\begin{array}{r}1107 \\
837\end{array}$ & $\begin{array}{r}1151 \\
837\end{array}$ \\
\hline \multicolumn{2}{|c|}{ Air entrainer $\left(\mathrm{mL} / \mathrm{m}^{3}\right)$, MB AE 90} & 135 & - & 142 & 142 \\
\hline \multicolumn{2}{|c|}{$\begin{array}{l}\text { Plasticizer }(\mathrm{mL} / 100 \mathrm{~kg}) \text {, } \\
\text { Pozzolith 322N }\end{array}$} & 228 & - & - & - \\
\hline \multicolumn{2}{|c|}{$\begin{array}{l}\text { Plasticizer* }^{*}(\mathrm{~mL} / 100 \mathrm{~kg}) \\
\text { Polyheed } 997\end{array}$} & - & 780 & 654 & 913 \\
\hline \multicolumn{2}{|c|}{ w/c ratio (plant) } & 0.409 & - & 0.275 & 0.367 \\
\hline \multirow{2}{*}{$\begin{array}{l}\geq \\
\stackrel{m}{\Sigma}\end{array}$} & $\begin{array}{l}\text { Corrosion inhibitor }\left(\mathrm{L} / \mathrm{m}^{3}\right) \\
\quad \text { Rheocrete } \mathrm{CNI}\end{array}$ & - & 30 & 24.8 & 24.8 \\
\hline & $\begin{array}{l}\text { Accelerator (L/100 kg), } \\
\text { Pozzutec } 20+\end{array}$ & - & 5.9 & 5.9 & 5.8 \\
\hline \multicolumn{2}{|c|}{ Extra water $\left(\mathrm{kg} / \mathrm{m}^{3}\right)$} & & - & 41.5 & - \\
\hline \multicolumn{2}{|c|}{$\begin{array}{l}\text { w/c ratio (at jobsite) } \\
\text { Apparent } \\
\text { Back-calculated }\end{array}$} & & $\begin{array}{l}0.409 \\
0.409\end{array}$ & $\begin{array}{l}0.497 \\
0.483\end{array}$ & $\begin{array}{l}0.473 \\
0.45\end{array}$ \\
\hline \multicolumn{2}{|c|}{ Temperature $\left({ }^{\circ} \mathrm{C}\right)$} & $21^{\dagger}$ & $10^{\ddagger}$ & $22^{* \star}$ & $10^{* * / 11^{\dagger \dagger}}$ \\
\hline \multicolumn{2}{|c|}{ Freezing point ${ }^{\ddagger \ddagger}\left({ }^{\circ} \mathrm{C}\right)$} & $-1^{* * *}$ & $-5^{\ddagger}$ & -4.3 & -4.7 \\
\hline \multicolumn{2}{|c|}{ Slump, mm } & $100^{* * *}$ & $150^{\ddagger}$ & 6.5 & 273 \\
\hline \multicolumn{2}{|c|}{ Air content (\%) } & $6-8^{\star \star \star}$ & $6-8^{\ddagger}$ & 3 & 11 \\
\hline
\end{tabular}

* A component of MB IV, but shown here as it replaces the plasticizer normally used in the standard concrete.

$\dagger \mathrm{ACl} 306$, warmest allowed.

‡ Target values for antifreeze concrete: mix $10^{\circ} \mathrm{C}$, freezing point $-5^{\circ} \mathrm{C}$, slump $150 \mathrm{~mm}$, air content $6-8 \%$.

** Temperature obtained from the outside of the mixing drum with a portable non-contact infrared thermometer.

i† Temperature obtained from thermocouple embedded in test sample.

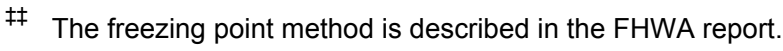

*** Typical values for freshly mixed standard concrete.

(Note that less than the suggested amount of corrosion inhibitor was used. Without this adjustment, the solids content of the mixing water would have been higher than the $15.7 \%$ needed to create $\mathrm{a}-5^{\circ} \mathrm{C}$ freezing point, as shown later in 
Figure 1.) Immediately following this, the accelerator was similarly pumped into the truck and mixed. At that point the concrete, having an apparent $\mathrm{w} / \mathrm{c}$ ratio of 0.38 (based on water metered into the mixture, water in the admixtures, and expected water in the aggregates divided by the weight of cement in the mixture) and a fair amount of plasticizer on board, should have had some slump. It had no slump. In fact, steam was noticed wafting out of the drum, which signaled that the cement might be suddenly hydrating. We quickly dumped numerous preweighed pails of cold water into the drum to re-establish some slump and to cool down the mix. At that point the apparent w/c ratio had increased to 0.497 , which was quite a bit higher than the target 0.409 and certainly higher than the 0.45 permitted in airfield pavements, so no more water was added and the concrete was tested. The resulting slump, air content and freezing point $-6.5 \mathrm{~mm}, 3 \%$, and $-4.3^{\circ} \mathrm{C}$, respectively - were unsatisfactory, and the concrete batch was discarded.

Why did the first trial batch fail? Critical clues to answering this question came from the temperature and freezing point measurements taken about one hour after initial mixing. At that time a $22^{\circ} \mathrm{C}$ temperature recorded from a cylinder of concrete made from the first batch suggested that the concrete almost certainly had been warmer while it was in the truck, as evidenced by the steam that was earlier seen coming out from the truck's drum. A high temperature such as this helps to explain why the concrete may have been so stiff. Temperatures above $20^{\circ} \mathrm{C}$ have caused some of our antifreeze concretes in the past to lose slump extremely rapidly, as happened this time. High temperature accelerates cement hydration and the rate of slump loss. [Korhonen et al. (2004) recommends a $10^{\circ} \mathrm{C}$ initial batching temperature so that by the time the concrete is placed, its internal temperature has not climbed too high.] Although the concrete producer used cold mixing water at our request, heated aggregates were also used, which, when combined with high doses of two fast-acting admixtures, created a hot mix that rapidly consumed water and lost slump.

Aggravating this apparent loss of slump was the prospect that the concrete had less water to consume than originally thought. We can say this because the $-4.3^{\circ} \mathrm{C}$ freezing point, when plotted on the curve in Figure 1, reveals that the solids content of the water in the concrete was $13.3 \%$. Unlike for normal concrete, the $\mathrm{w} / \mathrm{c}$ ratio of antifreeze concrete is determinable simply by measuring the freezing point (see Fig. 3 for an example) of a small sample of concrete and knowing its relationship to the concentration of admixtures in the concrete. As explained in the FHWA report, the solids content value along with the amounts of cement and admixtures used to make the concrete, which usually are fairly accurately known, can be used to back-calculate the actual $\mathrm{w} / \mathrm{c}$ ratio of the concrete (Table 1). In this case, it was back-calculated to be 0.483 and not the appar- 
ent 0.497 . Thus, the concrete was drier than expected. A likely explanation for this dryness is that the free moisture content of the sand and coarse aggregate was probably less than the $3 \%$ and $0 \%$ values, respectively, used by the ready-mix plant computers. Unfortunately, time did not allow us to check aggregate moisture contents to confirm this, which is always a good idea to do.

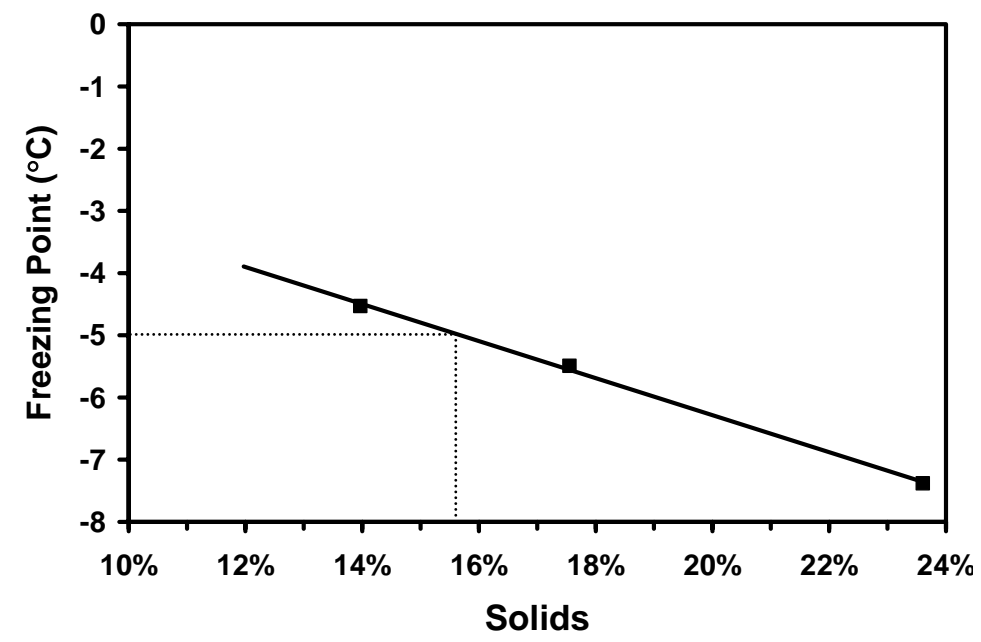

Figure 1. Relationship between the concentration of solids contributed by the admixtures to the water in the concrete and the freezing point of freshly mixed concrete made with admixture combination MB IV. (From Korhonen et al. 2004.)

Based on the first results, three adjustments were made to the second trial batch. First, the sand was estimated at $2.8 \%$ moisture instead of $3 \%$. Then, to improve workability, the initial $\mathrm{w} / \mathrm{c}$ ratio and the plasticizer dosage were increased from 0.275 to 0.367 and from $654 \mathrm{~mL} / 100 \mathrm{~kg}$ to $913 \mathrm{~mL} / 100 \mathrm{~kg}$, respectively. And finally, cold aggregate from the outdoor stockpile was used. As Table 1 shows, slump, air content, and freezing point measurements were greatly improved this time. In fact, both slump and air content improved too much; the 273-mm slump and the $11 \%$ air content were higher than the target $150-\mathrm{mm}$ slump and $6-8 \%$ air content. The $-4.7^{\circ} \mathrm{C}$ freezing point, on the other hand, did not quite achieve the target $-5^{\circ} \mathrm{C}$ value, but then the apparent $0.473 \mathrm{w} / \mathrm{c}$ ratio was higher than the target 0.409 .

A third trial batch was not considered necessary, as we felt that this mix only needed fine-tuning to make it acceptable. For example, the freezing point could easily be improved by just reducing the water content and, by doing that, also return the high slump to more normal levels. And using a smaller dosage of the 
air-entraining admixture could remedy the high air content of the second trial. Further, the sequence of dosing the corrosion inhibitor followed by the accelerator could be switched to alleviate the tendency for rapid slump loss. Based on our experience, this switch could create more working time because the fastest-acting admixture, the corrosion inhibitor, would be added into the mix last. We were ready to make concrete for the repair section.

\section{The Jobsite}

Figure 2 shows the repair section prepared to receive the antifreeze concrete. It was an unreinforced concrete pavement located in a non-trafficked area of a parking apron off the southwest end of the runway. It measured approximately $4.25 \mathrm{~m}$ wide by $7 \mathrm{~m}$ long by $0.6 \mathrm{~m}$ deep. Three locations were instrumented with thermocouples at three depths: $25 \mathrm{~mm}$ below the finished surface, at the center of depth, and directly on the base course. As shown, the three thermocouple strings were located at the edge, corner, and center of the slab. The edge and corner strings measured temperatures about $25 \mathrm{~mm}$ inboard of the existing concrete. All thermocouples were attached to a datalogger set to record at half-hour intervals.

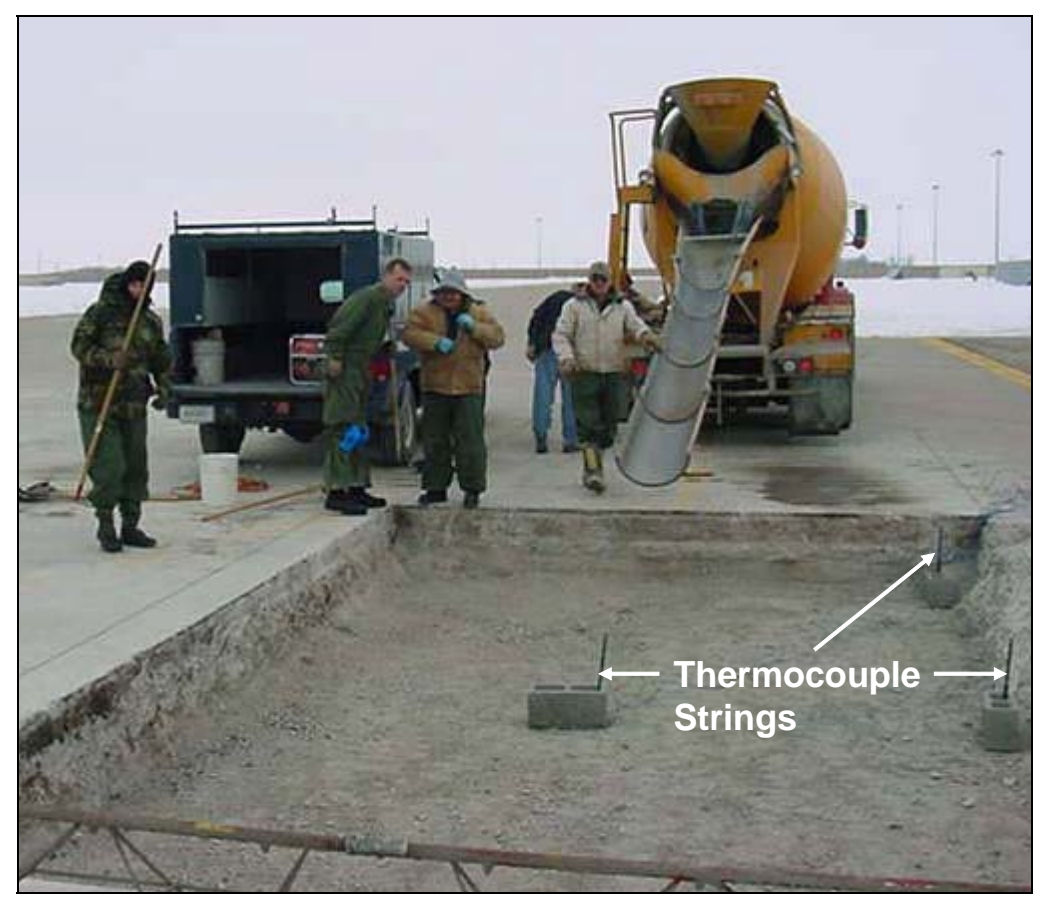

Figure 2. Repair section instrumented with thermocouples. 


\section{Batching the Concrete}

Four truckloads of concrete were sequentially batched at the ready-mix plant in Grand Forks on Tuesday morning and driven about $40 \mathrm{~km}$ east to a hangar on the Air Base, where they were dosed with the accelerator and corrosion inhibitor before proceeding about $2 \mathrm{~km}$ more to the jobsite. In good conditions the haul time to the hangar should have taken about a half hour. However, because the Air Police had not been properly notified of this job, and gaining access to the base would depend on how long it took for the guards to thoroughly inspect each truck, we decided not to have the ready-mix plant batch successive loads until the previous one had cleared security. Table 2 shows that each truckload was prepared at the ready-mix plant according to the second trial batch proportions except that the design $\mathrm{w} / \mathrm{c}$ ratio was reduced from 0.367 to 0.31 and the dosage of air-entraining admixture was reduced from 142 to $99 \mathrm{~mL} / \mathrm{m}^{3}$ and below, depending on the load.

Table 2. Mixture proportions for the four truck loads $\left(4.8 \mathrm{~m}^{3}\right.$ each) of antifreeze concrete used in this project.

\begin{tabular}{|c|c|c|c|c|c|}
\hline Location & Ingredient & Load 1 & Load 2 & Load 3 & Load 4 \\
\hline \multirow{7}{*}{ 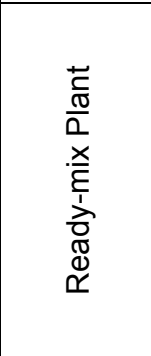 } & Cement $\left(\mathrm{kg} / \mathrm{m}^{3}\right)$ & 362 & 366 & 362 & 364 \\
\hline & Coarse aggregate $\left(\mathrm{kg} / \mathrm{m}^{3}\right)$ & 1099 & 1145 & 1143 & 1145 \\
\hline & Fine aggregate $\left(\mathrm{kg} / \mathrm{m}^{3}\right)$ & 811 & 842 & 832 & 838 \\
\hline & Water $\left(\mathrm{kg} / \mathrm{m}^{3}\right)$ & 87 & 87 & 88 & 88 \\
\hline & Air entrainer $\left(\mathrm{mL} / \mathrm{m}^{3}\right)$ & 99 & 99 & 62 & 68 \\
\hline & Plasticizer, PH 997 (mL/100 kg) & 916 & 907 & 920 & 913 \\
\hline & w/c ratio (apparent) & 0.31 & 0.31 & 0.31 & 0.31 \\
\hline \multirow{6}{*}{$\begin{array}{l}\frac{0}{50} \\
\frac{1}{0} \\
\frac{0}{2}\end{array}$} & Accelerator (L/100kg) & 6.8 & 7.1 & 5.9 & 6.2 \\
\hline & Corrosion inhibitor $\left(\mathrm{L} / \mathrm{m}^{3}\right)$ & 21.3 & 21.3 & 24.8 & 23.5 \\
\hline & Extra water $\left(\mathrm{kg} / \mathrm{m}^{3}\right)$ & 0 & 5.3 & 0 & 0 \\
\hline & $\begin{array}{l}\text { Super plasticizer }(\mathrm{mL} / 100 \mathrm{~kg}) \text {, } \\
\text { Glenium } 3000 \mathrm{NS}\end{array}$ & 0 & 0 & 84 & 0 \\
\hline & w/c ratio (apparent) & 0.41 & 0.43 & 0.42 & 0.42 \\
\hline & Concrete temperature ${ }^{*}\left({ }^{\circ} \mathrm{C}\right)$ & $\dagger$ & 8 & 7 & 11 \\
\hline
\end{tabular}

Obtained by measuring the outside temperature of the truck's drum with a noncontact infrared thermometer.

$\dagger$ Not measured.

The first truckload of concrete was batched at 7:53 a.m. After traveling to the Air Base and spending about 30 minutes clearing security, it finally arrived at the hangar at 8:50. It was then dosed with the accelerator, mixed for a few minutes, and then dosed with the corrosion inhibitor, which, as planned, was in opposite 
order to the trial batches. (Inadvertently, the dosages for these admixtures were not likewise switched. That is, the accelerator was dosed in the amount of the corrosion inhibitor and vice versa. This error was not corrected until the third truck.) After mixing the concrete for another 3 minutes, it seemed very workable, so the truck departed from the hangar for the jobsite at approximately 9:07. Though no temperatures were taken at the hangar, because the noncontact thermometer had not yet been delivered to the jobsite, the concrete appeared to be reasonably cool, as the outside of the mixing drum felt cool to the touch. This concrete, having an apparent $\mathrm{w} / \mathrm{c}$ of 0.41 , was behaving as anticipated.

The second truck was batched at 9:05 a.m., shortly after the ready-mix plant received word that the first truck had cleared security. It eventually arrived at the hangar at 9:50 and, with it, came the thermometer. The temperature of the concrete was immediately determined to be $8^{\circ} \mathrm{C}$. Between 9:55 and 10:04, the two admixtures were pumped into the truck, where, soon after, it became obvious that this concrete was not behaving like the previous mix. It was very stiff. A second temperature reading revealed that the concrete temperature had not changed, which implied that the mix might be overly dry but not rapidly hydrating, as experienced with the first trial batch the day before. Thus, on the hunch that it was a dry mix, we added more water along with extra accelerator into the concrete until it began to exhibit slump. [This hunch was later confirmed to be true by the lower-than-expected freezing points measured at the jobsite (Table 3).] At this point, we were not certain how dry the mix was, so, rather than risk overwatering the concrete, no more water was added. The temperature of the concrete was still $8^{\circ} \mathrm{C}$, so the truck was released to the jobsite with an apparent $\mathrm{w} / \mathrm{c}$ ratio of 0.43 and an estimated slump of $60 \mathrm{~mm}$.

Table 3. Properties of the fresh concrete.

\begin{tabular}{|lccccc|}
\hline \multicolumn{1}{c}{ Property } & Target & Truck 1 & Truck 2 & Truck 3 & Truck 4 \\
\hline Slump $(\mathrm{mm})$ & $150^{*}$ & 178 & $70^{\dagger}$ & 203 & $\mathrm{na}^{* *}$ \\
Air content $(\%)$ & $6-8$ & 12.5 & $6.8^{\dagger}$ & 9.0 & na $^{* *}$ \\
Temperature $\left({ }^{\circ} \mathrm{C}\right)$ & $10-20$ & 17 & $20^{\dagger}$ & 20 & na $^{* *}$ \\
Unit weight $\left(\mathrm{kg} / \mathrm{m}^{3}\right)$ & unknown & 2191 & 2287 & 2243 & $\mathrm{na}^{* *}$ \\
Freezing point $\left({ }^{\circ} \mathrm{C}\right)$ & -5.0 & -6.7 & $-7.2^{\dagger \dagger}$ & -8.0 & -5.5 \\
& & & $-6.0^{\dagger \dagger}$ & & \\
& & & $-5.1^{\dagger \dagger}$ & & \\
\hline
\end{tabular}

The target slump of antifreeze concrete is intentionally set higher than that of the standard concrete to account for rapid slump loss.

$\dagger$ Coincides with the second freezing point measurement below.

" Measurement not taken.

${ }^{\dagger \dagger}$ Freezing point obtained from the concrete as it arrived and after two subsequent additions of water. 
The third truck was batched at 9:35 a.m. and was dosed with the two admixtures at the hangar by 10:35. (The dosages for the accelerator and corrosion inhibitor were corrected.) After mixing for 3 minutes, the concrete's temperature was $7^{\circ} \mathrm{C}$, and its slump was visually determined to be $50 \mathrm{~mm}$. Instead of adding more water to improve the slump, because the apparent $\mathrm{w} / \mathrm{c}$ ratio was already at 0.42 , a small amount of superplasticizer was added. The concrete subsequently left the hangar with an apparent $125-\mathrm{mm}$ slump and a $7^{\circ} \mathrm{C}$ temperature at 10:45.

The final truck was batched at 10:46 a.m. In response to the lower-thantarget slump of the previous batch, the accelerator, because it contained a plasticizer, was slightly increased in dosage and the corrosion inhibitor dosage was slightly decreased to improve workability without affecting the freezing point. This slight modification seemed to have worked, as the concrete left the hangar with an apparent slump of $150 \mathrm{~mm}$, an $11^{\circ} \mathrm{C}$ temperature, and an apparent w/c of 0.42. This was the best batch of the four.

\section{Placing the Concrete}

The first truckload of concrete arrived at the jobsite at 9:15 a.m. and was completely discharged of its load 15 minutes later. After about a third of the load had been discharged, at approximately 9:20, a wheelbarrow of concrete was obtained from the truck for measuring slump, air content, temperature, unit weight and freezing point (Fig. 3). As shown in Table 3, when compared to target values, its slump and air content were high, its temperature was acceptable, and its freezing point was much better than expected. The concrete remained workable throughout placement and rapidly hardened thereafter, allowing workers to walk on it, without sinking very much into it, by the time the second truck arrived. (This was true for each load of concrete.) Except for the high air content, this mix exceeded our expectations.

The second truck arrived at approximately 10:15 a.m. Knowing that this concrete started out from the hangar with a $60-\mathrm{mm}$ slump, the driver began to discharge his load as soon as the truck was in position. As expected, the first concrete to come down the chute was very difficult to work with by hand (its slump was now estimated at $40 \mathrm{~mm}$ ). Placement would have continued, but within a few minutes the concrete unexpectedly lost all slump and would not come down the chute on its own. The concrete obviously needed more liquid. However, hot water from the truck's tank was all that was available. We did not want to overheat the mix, but, because the concrete started out relatively cool, we felt that using hot water would not present a problem. [Korhonen et al. (2004) cited an instance where hot water was similarly used to successfully retemper a stiff mix.] The truck driver added enough hot water to re-establish minimal slump. Samples taken from this portion of the load showed that the concrete had a slump of 70 


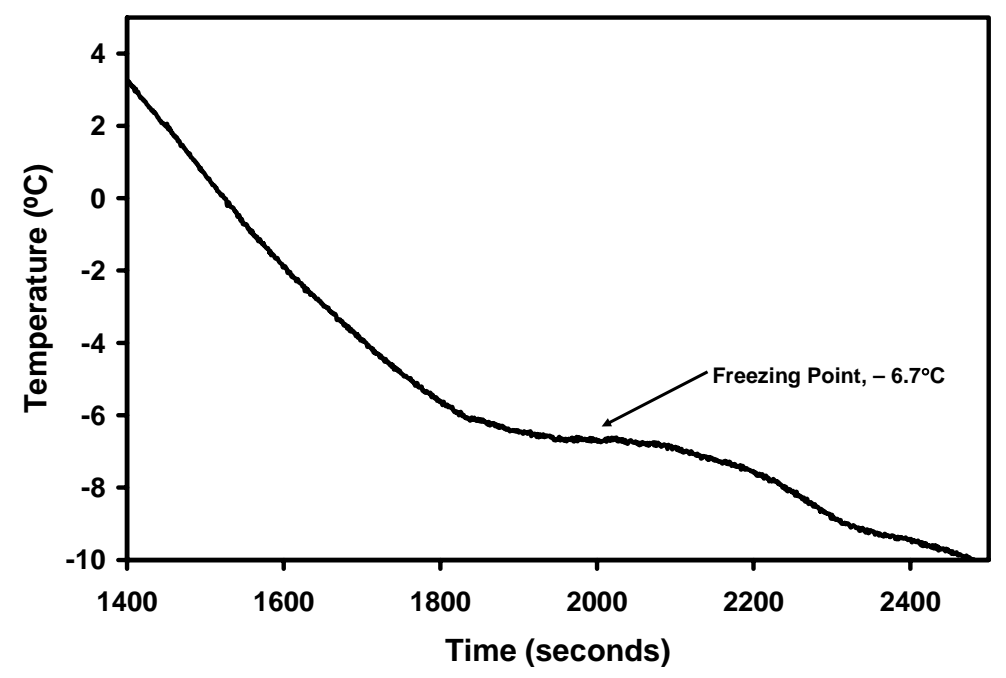

Figure 3. Freezing points determined by placing $50.8-$ by 101.6-mm cylinders of concrete into a picnic cooler containing dry ice. The freezing is identified as the temperature where the slope of the cooling curves flattens out. This is from one cylinder from Truck 1.

$\mathrm{mm}$, an air content of $6.8 \%$, a temperature of $20^{\circ} \mathrm{C}$, and a freezing point of $-6^{\circ} \mathrm{C}$, which are all acceptable values. However, this concrete again quickly lost all workability, and, once more, the driver added hot water into the mix. This time the remaining load was discharged at an observed slump of $100 \mathrm{~mm}$. Comments from the concrete workers indicated that this was a difficult load to work with for obvious reasons. Why it did not meet our expectations for workability did not become clear until later, when the inside of the truck's mixing drum was inspected (discussed later). Despite all the excess water that was added to this mix, the final freezing point met our goal at $-5.1{ }^{\circ} \mathrm{C}$.

The third truck arrived at approximately 10:55 a.m. It was completely offloaded within 15 minutes. Samples taken of this concrete show that it had the highest slump thus far at $203 \mathrm{~mm}$, its air content was nearly within the recommended range at $9 \%$, and its freezing point was remarkably low at $-8^{\circ} \mathrm{C}$.

The fourth truck arrived at approximately 11:40 a.m. and was completely discharged of its load within 15 minutes. The concrete workers commented that this was the best load of the four. It behaved much like the first load but with a lower estimated slump of $150 \mathrm{~mm}$. Though most measurements were not obtained from this load because of scheduling conflicts with the commercial lab, its $-5.5^{\circ} \mathrm{C}$ freezing point suggests that this batch of concrete probably came closest to meeting all design goals. 


\section{Finishing the Concrete Surface}

The concrete was layered truckload by truckload into the repair section. Thus, the work of finishing the concrete consisted of placing each layer with the truck's chute, raking it into final position (Fig. 4), and consolidating it with an internal vibrator. The top layer was leveled and compacted with a vibratory screed (Fig. 5). Because the concrete was rapidly setting, the surface was immediately finished with a magnesium bull float (Fig. 6) to embed aggregate and to further smooth it. Following the floating process, the surface was broomed (Fig. 7), and then the slab was edged (Fig. 8) and covered with 25-mm-thick insulation blankets (Fig. 9), not so much for thermal protection but to minimize evaporation, as the day was windy. The slab was sprayed with a curing compound the following morning when the blankets were removed.

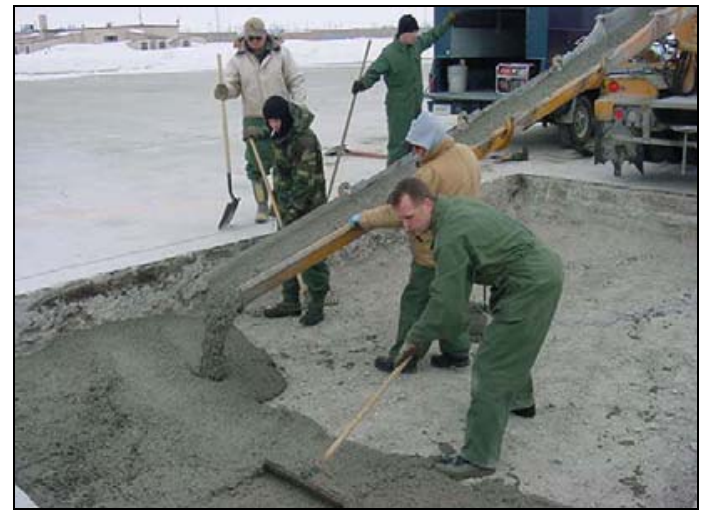

Figure 4. Placing and raking intermediate layers of concrete.

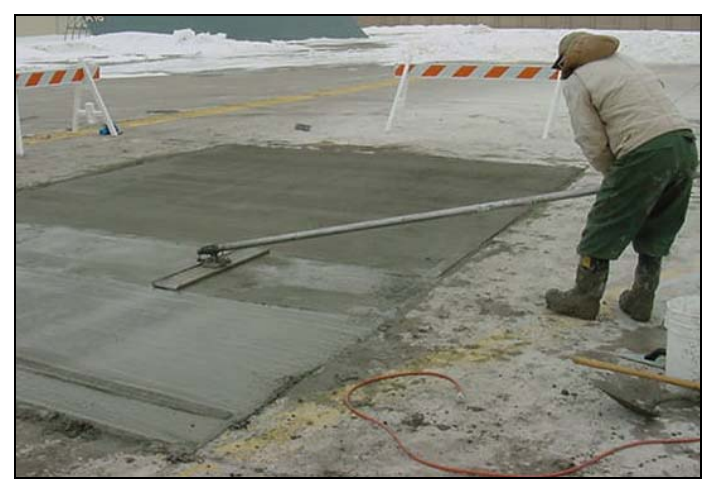

Figure 6. Floating.

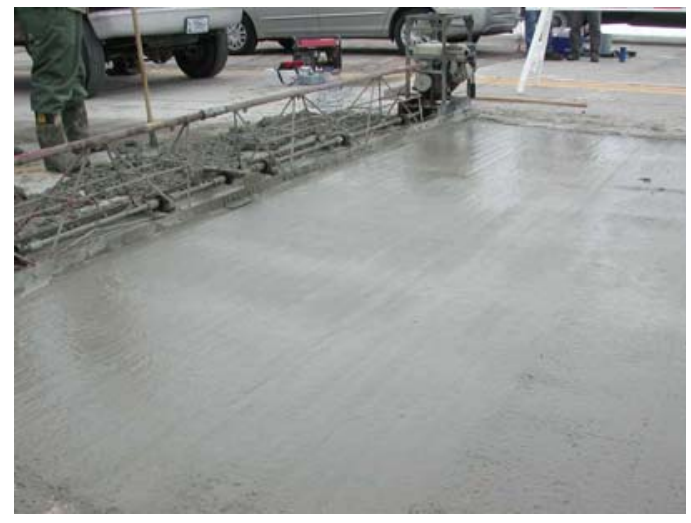

Figure 5. Screeding the top layer of concrete.

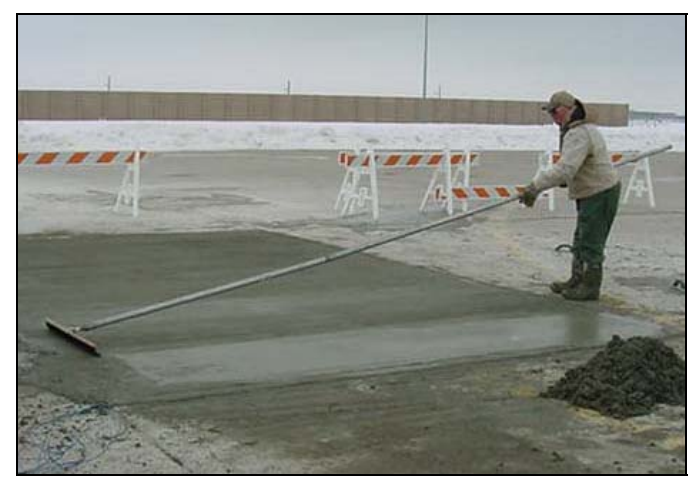

Figure 7. Brooming. 


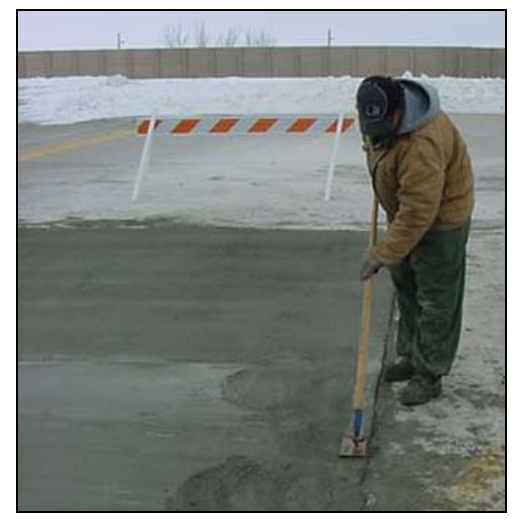

Figure 8. Edging.

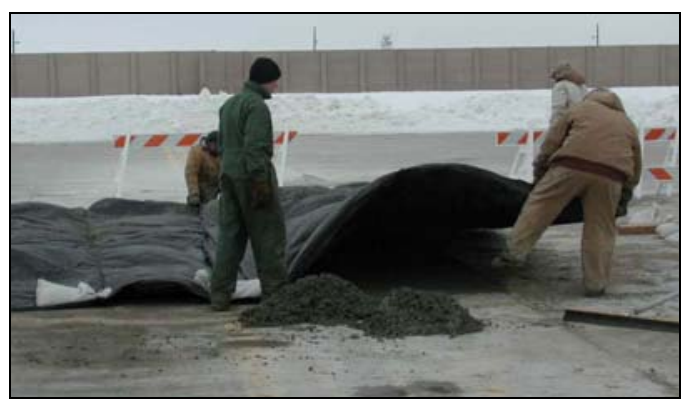

Figure 9. Laying insulation blankets in the wind and holding them down with sand bags.

\section{Strength Development}

To estimate the compressive strength developed in the slab over time, we compared strength data from test samples made from the third truckload of concrete to maturity data recorded by the datalogger. The compressive data were obtained from fifteen cylinders ( 150 by $304 \mathrm{~mm}$ ) that were cast and stored in insulated plywood boxes placed near the repaired section. Two of these cylinders were instrumented with thermocouples embedded at their centers. All cylinders were transported to a commercial laboratory 24 hours later, stripped from their molds, and, except for three cylinders that were immediately tested for strength, placed in water baths maintained at about $20^{\circ} \mathrm{C}$. Table 4 shows the resulting strength and maturity data obtained from the thermocouples embedded in the cylinders, along with corresponding estimated flexural strengths. The strength developed by the cylinders does not directly represent the strength developed by the slab because strength gain is a function of both the curing time and the curing temperature of the slab, and the temperature of the cylinders was always different from that of the slab. Thus, the Figure 10 maturity curve was developed from the compressive strength data and time-temperature history obtained from the instrumented cylinders. The slab's strength was then estimated by plotting the time-temperature history recorded from the slab for each day onto the maturity curve. 
Table 4. Compressive strength and maturity index data from cylinders cured 24 hours in the field and the rest of the time in standard laboratory conditions. Flexural strength was approximated from an empirical relationship after Neville (1988).

\begin{tabular}{|c|c|c|c|}
\hline $\begin{array}{l}\text { Curing time* } \\
\text { (hr) }\end{array}$ & $\begin{array}{c}\text { Compressive strength }{ }^{\dagger} \\
\text { (MPa) }\end{array}$ & $\begin{array}{l}\text { Flexure strength } \\
\text { (MPa) }\end{array}$ & $\begin{array}{l}\text { Maturity index }{ }^{* *} \\
\left({ }^{\circ} \mathrm{C}-\mathrm{hr}\right)\end{array}$ \\
\hline 24 & 15.9 & 3.25 & 583 \\
\hline 30 & 17.4 & 3.40 & 735 \\
\hline 45 & 18.8 & 3.57 & 1154 \\
\hline 54 & 20.6 & 3.80 & 1409 \\
\hline 72 & 22.0 & 3.90 & 1912 \\
\hline
\end{tabular}

* Initiated when cylinders were prepared.

$\dagger$ Average of three breaks.

** Nurse-Saul method with $-7^{\circ} \mathrm{C}$ datum temperature. Initiated when concrete was completely mixed: about 15 minutes before cylinders were cast.

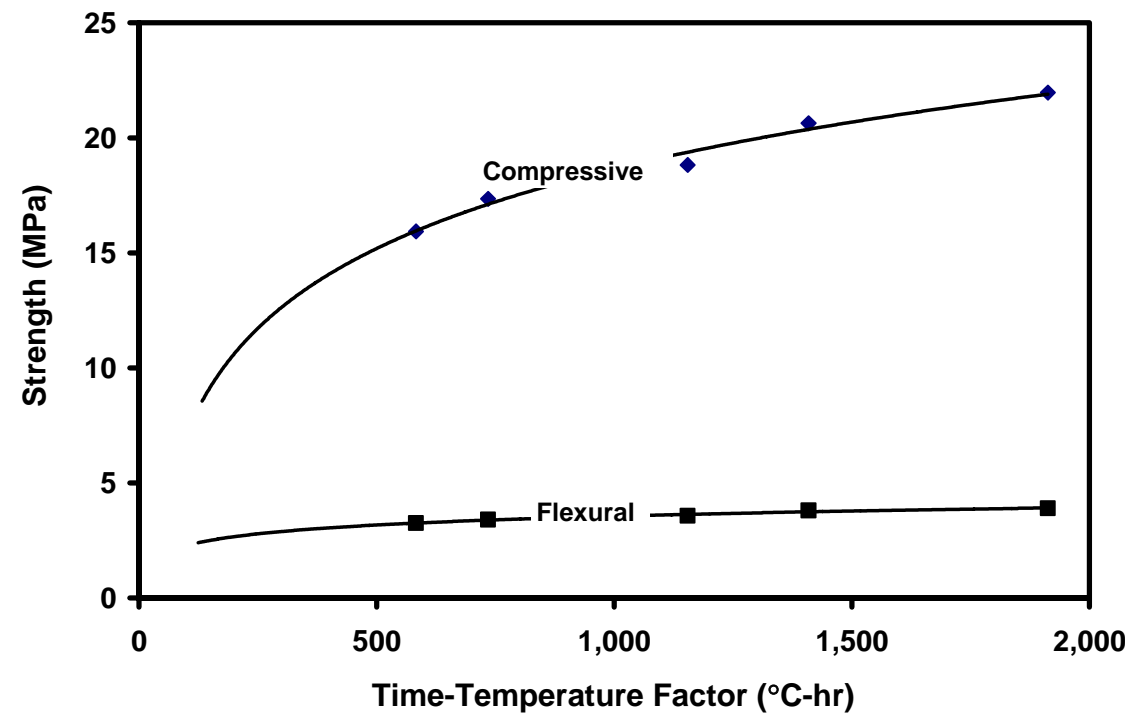

Figure 10. Maturity curve based on compressive strengths and time-temperature history from the cylinders cast during placement of the slab. The flexural strength is estimated.

The resulting strength development curves for three of the nine thermocouple locations in the slab are shown in Figure 11. As can be seen, strength developed rapidly over the first nineteen hours before the insulation blanket was removed at approximately 6:00 a.m. on Wednesday morning. At that time the warmest part of the concrete, the top $25 \mathrm{~mm}$ at the center of the slab, had developed a compressive strength of $17 \mathrm{MPa}$, whereas the bottom of the concrete, that in contact 
with the substrate, had developed 13 and $11 \mathrm{MPa}$ at the center and corner, respectively. Meanwhile, the flexural strength at the bottom of the slab was between 2.6 to $3.6 \mathrm{MPa}$, depending on location.

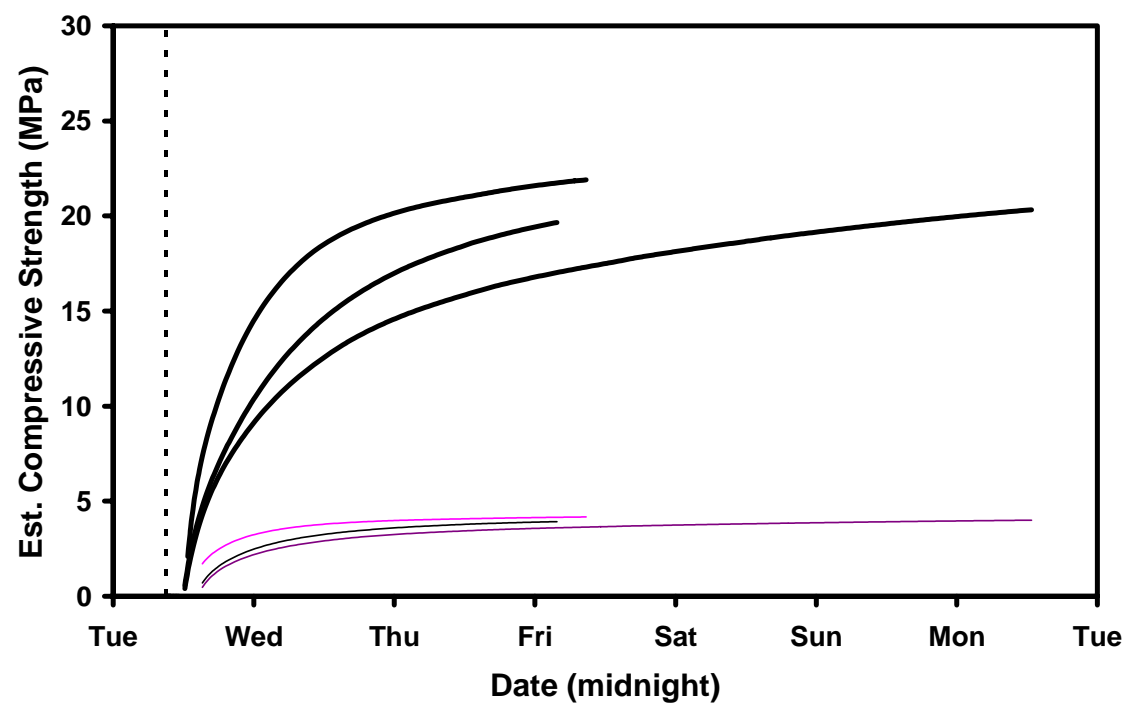

Figure 11. Predicted strength using the maturity curve from the cylinders and the time-temperature history from the top, bottom, and corner thermocouple locations. The top three lines show compressive strength; the bottom three lines show flexural strength.

\section{Temperatures}

Figure 12 shows the temperatures of the three slab locations shown in Figure 11 plus that of the ambient outdoor air. In general, the entire cross section of concrete, from the top to the bottom, continually warmed up from when it was placed until the insulation blanket was removed, when it began to cool down. The top $25 \mathrm{~mm}$ of concrete increased from its initial $15^{\circ} \mathrm{C}$ placement temperature at noon on February 24 to nearly $40^{\circ} \mathrm{C}$ by 6:00 a.m. on February 25. Almost immediately thereafter, this near-surface layer of concrete cooled abruptly when exposed to the windy $-2{ }^{\circ} \mathrm{C}$ air, when the insulation was removed. The bottom locations also warmed up, but not as dramatically because they were in contact with frozen ground, estimated at $-4^{\circ} \mathrm{C}$. (Typically, concrete is never placed on

* Personal communication with John W. Enz, Director, Department of Soil Science, North Dakota State University, Fargo, ND 58105, who referred to data from the North Dakota Agricultural Weather Network Center (NDAWN). 
frozen ground, but with antifreeze concrete that is now possible.) At the slab's center, the concrete quickly cooled off from its $17^{\circ} \mathrm{C}$ placement temperature to about $3^{\circ} \mathrm{C}$ when it came in contact with the ground, but, almost as quickly, it began to heat up again. It reached approximately $16^{\circ} \mathrm{C}$ before it began to feel the effects of the insulation being removed at 6:45 p.m. on Wednesday, February 25. The corner section, influenced by both the cold ground and two sides of the existing concrete, warmed from $3^{\circ} \mathrm{C}$ to only $6^{\circ} \mathrm{C}$ by $4: 15$ p.m., Wednesday, before it began to cool. The entire slab continued to cool, becoming essentially isothermal at $1.3^{\circ} \mathrm{C}$ at 2:15 p.m. on Tuesday, March 2, before ending up at $-0.5^{\circ} \mathrm{C}$ at 10:45 a.m. on Wednesday, March 3, when the datalogger was disconnected.

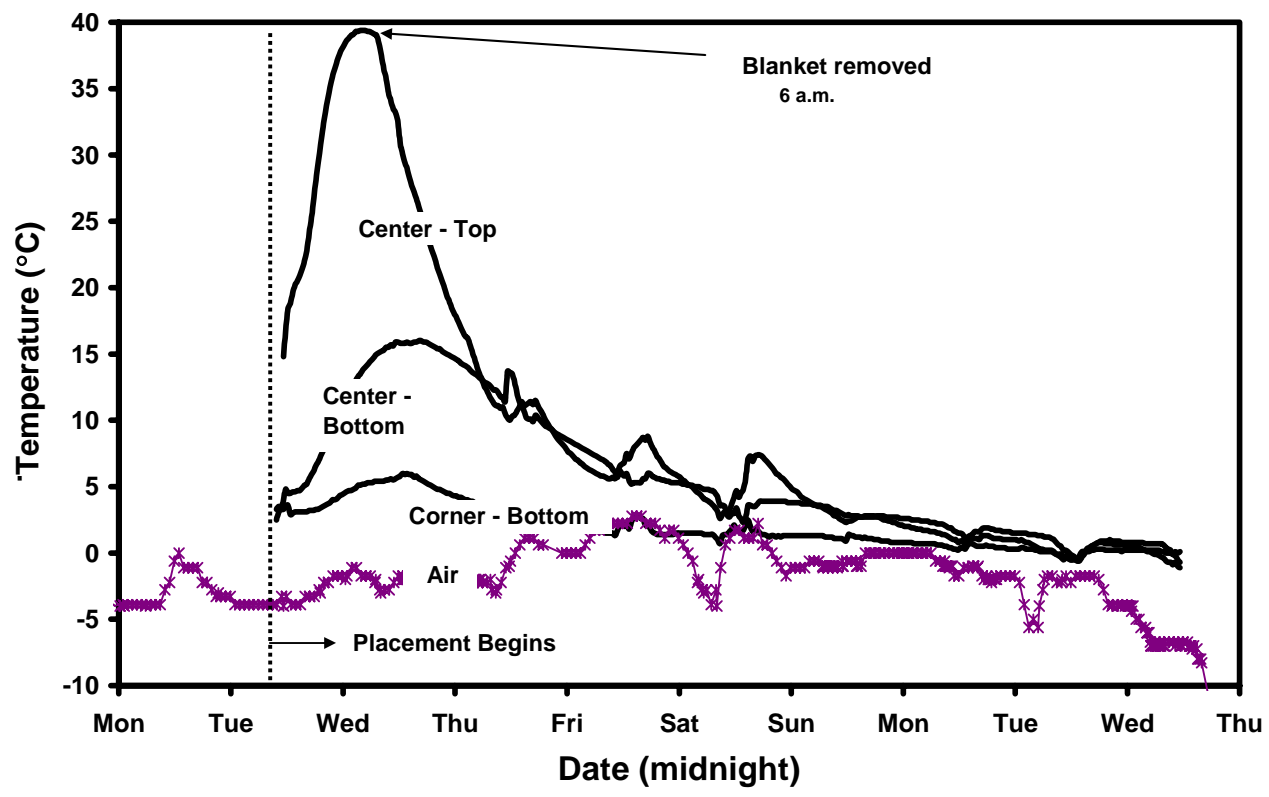

Figure 12. Temperatures from three locations in the slab and the ambient air from February 23 through March 3. 


\section{DISCUSSION}

In general, the antifreeze concrete developed in this project behaved like normal fast-setting concrete during mixing, at the time of placement, and throughout finishing. The second truckload was the exception-its concrete started out very stiff, even with the full complement of admixtures, and it remained fairly stiff even after extra water was added to it at the jobsite. It was later determined that the fins inside the truck's drum were damaged. A visual inspection showed that the top curve and some portions of the fins were bent and corroded, and on other fins the top curve was missing altogether. The mixing action of the drum was more like an auger that moves material forward rather than a mixer that both folds and moves material. Thus, the admixtures and water could not be as efficiently intermixed into the concrete with this truck as they were with the other three trucks, which had drums in better repair. The poor workability of this load of concrete was attributed to the inefficient mixing action of the truck, as opposed to something caused by the admixtures.

Table 3 shows that the freezing points of the four truckloads, when they arrived at the jobsite, were lower than expected - the first three truckloads had especially low freezing points. This meant that the concentration of solids from the admixtures in the concrete's water was higher than calculated, which, if the freezing point data are accurate, could only result from there being less water, more admixture in the mix than designed, or both. Unfortunately our freezing point measurements, as currently configured, could not be developed fast enough for us to react to this situation until after the concrete was placed. Hence, a check on the moisture content of the sand a day later revealed that a grab sample taken from the heated silo contained $1.65 \%$ free moisture, which indeed was drier than the estimated $2.8 \%$ used during the job. No checks were made on the coarse aggregate, but its moisture content could have also been dryer than that assumed for the job. Likewise, the admixture pumps were checked sometime later and found to deliver "reasonably" close to a 15-L line drawn inside a bucket. Of course, neither test, taken at a different time and from a different lot of material, provides conclusive evidence about what occurred on the job. Had we known within, say, 20 minutes after the first truck arrived that its load had such a low freezing point, we would have felt more confident in adding extra water to the next truckload to achieve the desired slump. Ideally, it would be good to have the freezing point data developed fast enough so that adjustments could be made on each truck before they discharged their loads. This supports our contention, raised during the FHWA study, that a quicker turn-around on the freezing point 
measurements would lead to better quality control of antifreeze concrete mixtures.

Compressive strength is a common indicator of concrete quality that is often used to specify when freshly placed concrete for bridges, buildings, and other structures can safely be put into service. For example, to prevent damage caused by freezing at early ages, it is critical that concrete achieve a compressive strength of at least 3.5 MPa before being exposed to one freeze-thaw cycle (ACI 2004). Clearly, Figure 11 shows that the concrete slab in this project became selfprotecting against frost within the first few hours of placement. However, at that time the concrete had not developed sufficient flexural strength to be serviceable. As a rule of thumb, pavements must attain at a flexural strength of least 3.5 to 4.5 MPa before they are safe to be opened to traffic. Although beams were not fabricated to test for flexural strength in this project, we used an empirical relationship between compressive and flexural strengths reported by Neville (1988) to estimate the flexural strength developed by the slab. (Other guidance for determining flexural strength is available from other sources as well.) As Figure 11 shows, this slab developed a flexural strength of $3.5 \mathrm{MPa}$ by noon on Thursday, February 26, 2004. Thus, this slab was potentially ready to be opened to traffic within two days after placement.

The concrete for this project was designed to resist freezing down to at least $-5^{\circ} \mathrm{C}$ and to gain appreciable strength while at that temperature. Even though the air temperatures hovered between $0^{\circ} \mathrm{C}$ and $-5^{\circ} \mathrm{C}$ for most of the first seven days following placement, Figure 12 shows that all portions of the slab remained well above freezing during that time. It was never in danger of freezing. In effect, the concrete could have been designed with fewer admixtures to produce the desired results. At this writing, research is being planned at CRREL to enable one to forecast internal concrete temperatures as a function of expected outdoor air temperatures and admixture dosage. This is being done because the users of this technology need to be able to predict how a concrete mixture will perform in a particular environment, making it possible to optimize mixture design, economize material costs, and assure desired outcomes.

Part of the reason that the concrete remained warm so long was that it was covered with insulation during the first nineteen hours. During that time the top surface of the slab had warmed up to nearly $40^{\circ} \mathrm{C}$ before it was suddenly exposed to freezing air. ACI (2004) warns against removing thermal protection too soon to avoid crack-inducing thermal strains between the inside and outside surfaces of the slab. To avoid such cracks, ACI recommends that the surface temperature of a slab 300-900 mm thick not be allowed to drop more than $22^{\circ} \mathrm{C}$ during any 24-hour period. As Figure 12 shows, the top surface of this slab, which was 610 
$\mathrm{mm}$ thick, dropped approximately $26^{\circ} \mathrm{C}$ in the 24 hours after the insulation was removed. As would probably occur for any concrete structure, the slab cracked (Fig. 13). In fact, we believe that it cracked during our inspection between 8:00 and 9:00 a.m. the morning following concrete placement, about 3 hours after the insulation was removed. The crack could probably have been avoided if the insulation had been left in place another day.

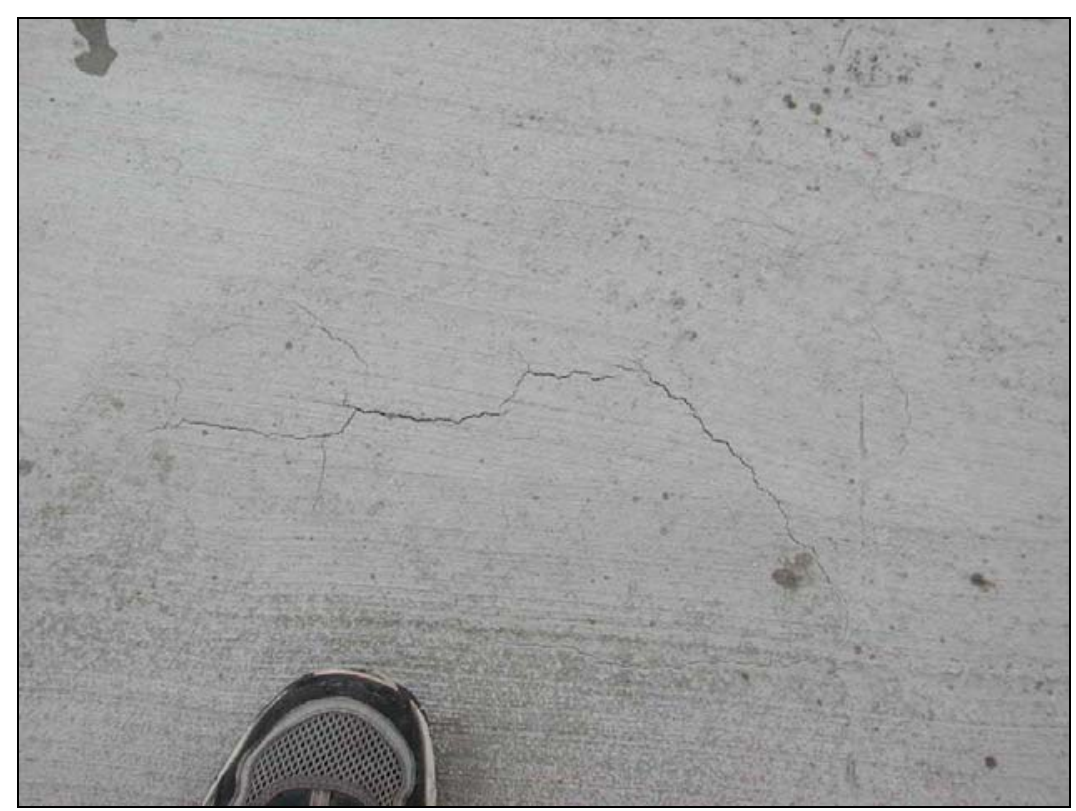

Figure 13. Crack that developed in the concrete approximately 3 hours after the insulation blanket was removed. 


\section{CONCLUSIONS}

This work demonstrates that USAF civil engineering squadrons and contractors alike can place portland cement concrete in winter conditions without the cumbersome and expensive conventional cold-weather placement methods required in the past. A critical advantage of using these admixtures is that they are already used routinely in concrete for other purposes, so no special specifications or permissions are required to use them in cold weather applications today.

The work showed that formulating antifreeze concrete in the field by mixing several off-the-shelf admixtures into standard concrete mixtures required no new skills. High doses of admixtures are commonly pumped, using specially designed equipment for this purpose, into concrete trucks at construction sites today. Thus, getting high doses of admixtures into our antifreeze concrete in the field simply followed the same techniques and used the same equipment. The primary difference between making standard concrete and making antifreeze concrete is that antifreeze concrete is made with cold water, not hot. Again, this presented no special problems to the ready-mix producer in this project because he could readily switch between cold water for antifreeze concrete and hot water for other standard concrete orders.

A long haul time, in this case longer than 1 hour, was handled by dosing most of the admixtures into the truck at the jobsite. This way the fast-acting admixtures could not react with the cement until the construction workers were ready for the concrete. This could be a distinct advantage should concrete trucks get backed up on future jobs.

Unlike conventional cold weather concreting techniques, the substrate did not have to be thawed before the antifreeze concrete was placed on it. This greatly simplified operations and reduced potential heating costs. Cleanup of equipment afterward was easily accomplished with the hot water normally carried by the truck. Placing and finishing operations were done in the usual manner, paralleling those for today's fast-track concretes used in summertime applications. As with normal concrete, once the antifreeze concrete is finished, it must be either covered with plastic or spray-applied curing compound to minimize moisture loss to facilitate curing.

Heated enclosures are not necessary with this technology, provided the weather does not get too cold. The FHWA report documents that a 130 -mm-thick concrete sidewalk was cured with no more than an insulation blanket in $-25^{\circ} \mathrm{C}$ 
air temperatures. This represents a tremendous potential thermal energy savings compared to using a heated shelter.

Antifreeze admixtures, made from off-the-shelf products, have potential application for both general construction and emergency repairs. 


\section{RECOMMENDATIONS}

The following areas need further study:

- Develop an automated device for rapidly measuring the freezing point of antifreeze concrete. Freezing point measurements are crucial for verifying that the concrete is properly mixed and dosed with admixtures. Though our readings became available shortly after the concrete was placed, the ability to measure the freezing point before the concrete is placed would allow adjustments to be made, or the concrete to be rejected, or some level of thermal insulation to be employed should the concrete not meet freezing point requirements.

- Develop the methodology to tailor the admixture dosage to the expected weather conditions. Currently our admixtures are designed to protect concrete to at least $-5^{\circ} \mathrm{C}$. However, as shown in this study and elsewhere, this much protection is not always necessary. In effect, the $-5^{\circ} \mathrm{C}$ concrete may be over-designed for many instances and thus more expensive than it has to be. Work needs to be done to be able to design various levels of admixture dosages to fit a wide range of job conditions.

- Conduct additional demonstrations on larger areas of pavement. Using slip-form pavers needs to be examined before this technology can be readied for larger-scale operations.

- Develop construction criteria. This technology must be adopted into standard construction criteria. 


\section{REFERENCES}

Korhonen, C. (2002) New developments in cold-weather concreting. In Proceedings of the $11^{\text {th }}$ International Conference on Cold Regions Engineering, 2022 May 2002, Anchorage, Alaska. Reston, Virginia: American Society of Civil Engineers.

Korhonen, C.J., P.M. Semen, and L.A. Barna (2004) Extending The Season For Concrete Construction And Repair: Phase I-Establishing the technology. Technical Report ERDC/CRREL TR-04-2, U.S. Army Engineer Research and Development Center, Cold Regions Research and Engineering Laboratory, Hanover, New Hampshire.

ACI (2004) Cold Weather Concreting. ACI 306R-88 (Reapproved 2002). Farmington Hills, MI 48333-9094: American Concrete Institute.

Neville, A.M. (1988) Properties of Concrete. Third edition. Essex, England: Longman Scientific and Technical. 


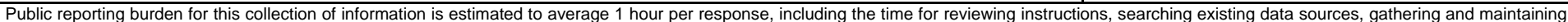

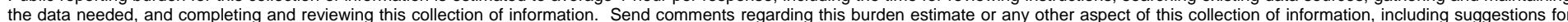

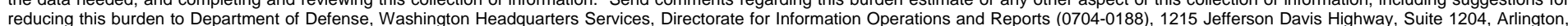

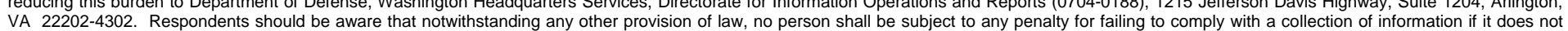
VA 22202-4302. Respondents should be aware that notwithstanding any other provision of law, no person shall be sube
display a currently valid OMB control number. PLEASE DO NOT RETURN YOUR FORM TO THE ABOVE ADDRESS.
1. REPORT DATE (DD-MM-YYYY)
2. REPORT TYPE

April 2005

4. TITLE AND SUBTITLE

Placing Antifreeze Concrete at Grand Forks Air Force Base

3. DATES COVERED (From - To)

5a. CONTRACT NUMBER

5b. GRANT NUMBER

5c. PROGRAM ELEMENT NUMBER

6. AUTHOR(S)

5d. PROJECT NUMBER

Charles Korhonen and Peter Semen

5e. TASK NUMBER

5f. WORK UNIT NUMBER

7. PERFORMING ORGANIZATION NAME(S) AND ADDRESS(ES)

8. PERFORMING ORGANIZATION REPORT NUMBER

U.S. Army Engineer Research and Development Center

Cold Regions Research and Engineering Laboratory

ERDC/CRREL TR-04-9

72 Lyme Road

Hanover, NH. 03755-1290

9. SPONSORING I MONITORING AGENCY NAME(S) AND ADDRESS(ES)

10. SPONSOR/MONITOR'S ACRONYM(S)

Office of the Chief of Engineers Grand Forks Air Force Base

Washington, DC 20314-1000 North Dakota

Master Builders, Inc.

Cleveland, Ohio

Office, Asst. Sec. of Army, Install. and Environment

11. SPONSOR/MONITOR'S REPORT NUMBER(S)

12. DISTRIBUTION / AVAILABILITY STATEMENT

Approved for public release; distribution is unlimited

13. SUPPLEMENTARY NOTES

\section{ABSTRACT}

The first airfield pavement application of a recently developed antifreeze technology for cold weather concreting was demonstrated in February 2004 on an unreinforced section of a parking apron at the Grand Forks Air Force Base (GFAFB) in North Dakota. The technology, which combines ordinary concrete admixtures into a formulation that depresses the freezing point of water and accelerates the hydration rate of portland cement, was the product of a three-year study conducted for the Federal Highway Administration and completed in February 2004. One of the eight admixture combinations developed in that study was used to convert a standard concrete mixture into antifreeze concrete at GFAFB. Two trial batches of concrete made on the day prior to working on the apron afforded the ready-mix producer ample time to adjust admixture dosages to produce a workable concrete. Four truckloads of concrete were sequentially batched at the ready-mix plant and dosed with the antifreeze formulation at the jobsite. Except for the second truckload, which was later discovered to have damaged mixing fins inside its drum, the antifreeze concrete batched in this study behaved like normal fast-setting concrete during mixing, at the time of placement, and throughout finishing. The apron section was ready for traffic two days after placement in subfreezing weather.

\section{SUBJECT TERMS}

Admixtures Cold weather concreting

Antifreeze concrete

16. SECURITY CLASSIFICATION OF:

\section{Concrete}

(16.

a. REPORT

U b. ABSTRACT

U c. THIS PAGE
$\mathrm{U}$

\begin{tabular}{l|c|} 
17. LIMITATION & $\begin{array}{c}\text { 18. NUMBER } \\
\text { OF ABSTRACT } \\
\text { OF PAGES }\end{array}$ \\
& \\
&
\end{tabular}

19a. NAME OF RESPONSIBLE PERSON

19b. TELEPHONE NUMBER (include area code) 